\title{
USE OF RIFAMPICIN-RESISTANT BACTERIAL BIOCONTROL STRAINS FOR MONITORING SURVIVAL IN SOIL AND COLONISATION OF PEA SEEDLING ROOTS
}

\author{
N. BOLSTRIDGE ${ }^{1,3}$, S. CARD ${ }^{1,4}$, A. STEWART ${ }^{1}$ and E.E. JONES ${ }^{2}$ \\ ${ }^{1}$ Bio-Protection Research Centre, Lincoln University, Lincoln, New Zealand \\ ${ }^{2}$ Agriculture and Life Sciences Faculty, Lincoln University, Lincoln, \\ New Zealand \\ ${ }^{3}$ Present address: Landcare Research New Zealand Ltd, Lincoln, New Zealand \\ ${ }^{4}$ Present Address: AgResearch Ltd, Grasslands Research Centre, Palmerston \\ North, New Zealand
}

Corresponding author: Eirian.Jones@lincoln.ac.nz

\begin{abstract}
Spontaneous rifampicin-resistant strains of two bacterial biocontrol agents, Bacillus subtilis and Paenibacillus polymyxa, with potential to control Aphanomyces euteiches root rot of peas, were used to assess bacterial survival in soil and colonisation of pea seedling roots. The growth and biocontrol characteristics of the rifampicin-resistant strains were similar to the wild type isolates. In two non-sterile soils (Methven and Courtenay), both bacterial strains survived at least 28 days when applied as inoculum containing high endospore numbers. However, when applied as mostly cells, no bacteria were recovered. Bacteria applied as seed coat formulations colonised both the rhizosphere and rhizoplane of the resulting pea seedlings, with higher recovery from the top 0-4 cm root section compared with the bottom 5-8 cm section. Apart from the top root section for P. polymyxa, where there was no difference in the recovery between the rhizoplane and rhizosphere, recovery of the bacteria was higher in the rhizoplane compared with the rhizosphere. Keywords: Aphanomyces euteiches, Paenibacillus polymyxa, Bacillus subtilis, rhizosphere, rhizoplane.
\end{abstract}

\section{INTRODUCTION}

Aphanomyces euteiches Drechsler causing root rot of peas is an important and destructive disease of Pisum sativum both in New Zealand and worldwide (Pfender 1984; Wakelin et al. 1998). Due to the lack of effective fungicides and non-availability of resistant cultivars, disease avoidance is currently the only control option, resulting in a recommended 6-year pea rotation in order to reduce A. euteiches inoculum (Oyarzun 1993). In addition to the loss of an economic crop, the removal of peas from crop rotations can lead to sustainability and productivity issues, as peas are often used in New Zealand as a disease break crop between cereals, whilst maintaining soil fertility (White 1987).

Wakelin (2001) identified a number of endospore-forming bacteria, including Bacillus subtilis strain LU1241 and Paenibacillus polymyxa strain LU1133, with potential to control A. euteiches. However, biocontrol efficacy by these bacterial strains was inconsistent in field experiments (Wakelin 2001; N. Bolstridge \& E.E. Jones, unpubl. data), which may have been due to the survival and colonisation ability of the biocontrol bacteria under different soil or environmental conditions. As A. euteiches infects plants both when they emerge and later in the season (King \& Parke 1996), biocontrol of the pathogen would potentially require the biocontrol agent to be present throughout the 
growing season, colonising both the seed and the rhizosphere. It is, therefore, essential that the colonisation and survival of applied biocontrol agents in soil can be monitored to assess the effect of different environmental factors, agronomic practices and soil types on their survival and hence biocontrol efficacy.

In preliminary experiments, detection of introduced wild type (WT) bacterial strains from non-sterile soil was not possible due to difficulties in distinguishing the introduced strains from the background populations. Due to these difficulties rifampicin-resistant mutant (RRM) strains of B. subtilis LU1241 and P. polymyxa LU1133 were produced to enable unambiguous identification of the introduced bacterial strains from the indigenous soil populations. This paper reports on the production of RRM strains, verification of their biocontrol traits compared to the wild type strains, and assessment of their survival rate in soil and their colonisation potential of the pea seedling rhizosphere. In addition, the proportion of total bacterial cells to endospores was enumerated to determine subsequent application strategies.

\section{Production of rifampicin-resistant mutants}

\section{MATERIALS AND METHODS}

Bacillus subtilis LU1241 and P. polymyxa LU1133 were isolated in Canterbury from the rhizosphere of a pea plant and an A. euteiches suppressive soil, respectively (Wakelin et al. 2002).

Spontaneous RRM, LU1241R and LU1133R, were selected by plating LU1241 and LU1133 on nutrient agar (NA; Oxoid) amended with $100 \mu \mathrm{g} / \mathrm{ml}$ rifampicin (NA+R; Sigma). Growth rates were comparable with the WT strains. Stability of the rifampicin resistance was confirmed by subculturing five times on NA in the absence of antibiotic selection and then on NA+R. The cultures were stored in $20 \%$ glycerol at $-80^{\circ} \mathrm{C}$ and routinely cultured onto NA plates and incubated at $28^{\circ} \mathrm{C}$ for 3 to 5 days.

\section{Bacterial inoculum preparation}

A single 3-day-old colony of the RRM was used to inoculate $10 \mathrm{ml}$ nutrient broth (NB; Difco) contained in $50 \mathrm{ml}$ centrifuge tubes. After incubation at $28^{\circ} \mathrm{C}$ for $16 \mathrm{~h}$, with shaking (180 rpm.), a $1 \mathrm{ml}$ aliquot was inoculated into $100 \mathrm{ml} \mathrm{NB}$, contained in $500 \mathrm{ml}$ flasks, and incubated at $28^{\circ} \mathrm{C}$ for $24 \mathrm{~h}$. The cells were harvested by centrifugation at $2952 \mathrm{~g}$ at $4^{\circ} \mathrm{C}$ for $5 \mathrm{~min}$ and washed twice with sterile distilled water (SDW). The cell pellet was re-suspended in $20 \mathrm{ml} \mathrm{SDW}$ to achieve an approximate concentration of $10^{8}$ cells $/ \mathrm{ml}$, determined by serial dilution plating (Bennett et al. 2003).

\section{Verification of mutant characteristics compared with the wild type}

Antagonistic activity of the RRM (LU1241R and LU1133R) compared with the WT strains was assessed by a dual-culture, in vitro assay against $A$. euteiches, isolate AE1, on potato dextrose agar (PDA; Oxoid). PDA plates were inoculated centrally with a fungal agar plug $(7 \mathrm{~mm})$ and inoculated with $10 \mu \mathrm{l}$ of NB bacterial broth at four equidistant points around the perimeter of the plate. Zones of inhibition were assessed after 10 days growth at $23^{\circ} \mathrm{C}$. Siderophore production by the bacterial strains was assessed on chrome azurol S (CAS) medium following the method of Alexander \& Zuberer (1991), whereby three CAS plates were inoculated centrally with $10 \mu \mathrm{l}$ of a NB bacterial culture. After incubation at $25^{\circ} \mathrm{C}$ for 3 days, the zone of discoloration of the medium (from blue to orange) around the bacterial colony, indicating siderophore production, was recorded. $\beta$-glucanase activity was determined using chromogenic (azurine-dyed cross-linked) substrates (Megazyme International Ireland Ltd, Bray, Ireland) as described by Opelt \& Berg (2004). The plates were examined after 5 days incubation at $22^{\circ} \mathrm{C}$ under UV light $(366 \mathrm{~nm})$ for fluorescence around the bacterial colony. Protease activity was determined from clearing zones in skim milk agar after 5 days incubation at $20^{\circ} \mathrm{C}$, as described by Opelt \& Berg (2004). In each assessment there were three replicate plates per treatment.

\section{Recovery of rifampicin resistant bacterial cells from non-sterile field soil}

In Experiment 1, the recovery and survival of the RRM cells from non-sterile field soil was investigated. Soil was collected from the top $20 \mathrm{~cm}$ at four random locations at two pea field trial sites, Courtenay (Templeton silt loam) and Methven (Horarata silt 
loam) and sieved through a $4 \mathrm{~mm}$ mesh. For each soil type, four replicate samples of $150 \mathrm{~g}$ soil were placed in $500 \mathrm{ml}$ sterile glass bottles and inoculated with either LU1241R or LU1133R to achieve a target inoculum concentration of $10^{7} \mathrm{cfu} / \mathrm{g}$ soil. Soil moisture was adjusted to $25 \%$ field water holding capacity using sterile water and the bottles sealed and incubated at $20^{\circ} \mathrm{C}$ in the dark for 4 days. Controls consisted of four replicates of each soil moistened with sterile water to $25 \%$ field water holding capacity.

After 1 day incubation, the soil was mixed by shaking, and ten $1 \mathrm{~g}$ subsamples were taken from the bulk sample, pooled and added to $90 \mathrm{ml} 0.01 \%$ water agar (WA). The soil/WA suspension was shaken for $10 \mathrm{~min}$ and, after standing for $5 \mathrm{~min}$, total colony forming unit (cfu) counts were determined by serial dilution plating onto three replicate plates each of NA and NA+R. Endospore concentrations were determined by plating $100 \mu \mathrm{l}$ aliquots of the serial dilutions onto NA+R after heat treatment of soil dilutions at $80^{\circ} \mathrm{C}$ for $20 \mathrm{~min}$. The number of colonies was counted after 3 days incubation at $28^{\circ} \mathrm{C}$ and the total cell and endspore counts per gram soil calculated. This was repeated after 4 days incubation.

Experiment 1 was repeated, except that this time the inoculum was produced from broth cultures grown for 5 days instead of 1 day to achieve higher endospore concentrations (Experiment 2). The inoculated soil was incubated at $20^{\circ} \mathrm{C}$ in the dark with soil samples taken after 1, 3, 8 and 28 days to determine total cfu and endospore numbers, as previously described.

Microbial survival and colonisation in the rhizosphere and rhizoplane of pea seedlings

The NB 5-day-old bacterial cultures were harvested and washed by centrifugation, as previously described, and resuspended in $5 \mathrm{ml}$ phosphate buffered saline (PBS) to achieve a target inoculum concentration of $2 \times 10^{8} \mathrm{cfu} / \mathrm{seed}$. Methyl cellulose $(0.2 \mathrm{~g})$ was added to $5 \mathrm{ml}$ of each bacterial suspension. Controls consisted of methyl cellulose amended PBS. Twenty surface sterilised pea seeds (cultivar 'Whero') were added to each of the centrifuge tubes containing the bacteria/methyl cellulose suspension or the $\mathrm{PBS} / \mathrm{methyl}$ cellulose suspension. These were shaken for $5 \mathrm{~min}$ and the contents poured into a sterile Petri dish lid and dried overnight under a sterile air flow. Total cell and endospore concentrations of the bacteria from the pea seed coat were assessed by serial dilution plating. Two pea seeds (approximately $500 \mathrm{mg}$ ) were shaken in $4.5 \mathrm{ml}$ SDW for $10 \mathrm{~min}$ and after standing for $5 \mathrm{~min}$, used for serial dilution plating on $\mathrm{NA}+\mathrm{R}$, as previously described.

Twelve $50 \mathrm{ml}$ centrifuge tubes, split in half lengthways with the two halves resealed using masking tape, were filled to the $50 \mathrm{ml}$ mark with sieved soil $(4 \mathrm{~mm})$ obtained from the Methven field site. One pea seed was placed on the surface of the soil and covered with soil, with four replicates for each of the three treatments (LU1241R, LU1133R and untreated control seeds). The soil was carefully watered with $10 \mathrm{ml}$ tap water and tubes were incubated at room temperature under natural light. When the roots had reached the bottom of the tubes (after 10 days) the tape and one half of the tube was removed to leave a cylinder of soil containing the pea root. The soil cylinder and root were cut into two portions, $0-4 \mathrm{~cm}$ (top) and 5-8 cm (bottom), and the rhizosphere soil carefully separated from the root. Recovery and survival of both total cell and endospores of the two bacterial strains was assessed by serial dilution plating, whereby a $10 \mathrm{~g}$ sample of the rhizosphere soil from both the top and bottom half of the tube was shaken in $90 \mathrm{ml}$ $0.01 \%$ WA and treated as previously described.

For enumeration of the two bacterial strains in the rhizoplane, root samples were shaken to free loose soil and the resulting root and attached soil was weighed before being shaken in $5 \mathrm{ml} 0.01 \%$ WA for $10 \mathrm{~min}$ and used for serial dilution plating, as previously described. The clean root was extracted, patted dry and reweighed to enable the quantity of rhizoplane soil to be determined.

\section{Statistical analysis}

To satisfy the assumption of normality for Analysis of Variance, cfu counts were $\log _{10}$ transformed, after the addition of 1 to allow for zero counts. Means of treatments were separated using Fishers Protected Least Significance Difference test, with all 
comparisons noted at a $\mathrm{P}=0.05$ significance level. For the recovery of the bacteria from soil, the initial counts were omitted from the analysis as these were based on applied and not recovered rates.

\section{RESULTS \\ Verification of mutant characteristics compared with the wild type}

All RRM gave similar results to those of the wild type. Both B. subtilis LU1241 and LU1241R showed the greatest inhibition of $A$. euteiches, producing an inhibition zone of 8-10 mm. Paenibacillus polymyxa LU1133 and LU1133R produced inhibition zones of 2-5 mm. The RRM also inhibited the growth of Gaeumannomyces graminis and Rhizoctonia cerealis to a similar level to the WT strains (data not shown). Both the WT and the RRM were positive for siderophore, protease and $\beta$-glucosidase production.

Recovery of rifampicin-resistant bacterial cells from non-sterile field soil

In Experiment 1, background concentrations of bacteria were 6.7 and $6.5 \log _{10} \mathrm{cfu} / \mathrm{g}$ soil for the Methven and Courtenay soils, respectively. The initial inoculum concentration applied to the soil was $6.9 \log _{10}$ cfu/g soil for B. subtilis LU1241R and $7.0 \log _{10} \mathrm{cfu} / \mathrm{g}$ soil for $P$. polymyxa LU1133R with endospore concentrations less than $2.0 \log _{10}$ endospores/g soil in both cases. No bacterial colonies were recovered on any of the rifampicin amended dilution plates at either sampling time ( 1 or 4 days incubation) for the uninoculated control soils or for either soils inoculated with LU1241R or LU1133R.

In Experiment 2, the initial inoculum level for B. subtilis LU1241R was $6.9 \log _{10} \mathrm{cfu} / \mathrm{g}$ soil with $5.2 \log _{10}$ endospores/g soil and $P$. polymyxa LU1133R had $6.9 \log _{10}$ cfu/g soil and $5.5 \log _{10}$ endospores/g soil (Fig. 1). No rifampicin-resistant colonies were recovered from the control soils. RRM were isolated from both the Courtenay and Methven soils throughout the experiment. The behaviour of both LU1241R and LU133R was broadly similar in the two soils, with the total bacteria cfu decreasing rapidly from the initial inoculum levels before increasing significantly from levels recovered at day 1 and 3 to level off at 5.7-5.9 $\log _{10} \mathrm{cfu} / \mathrm{g}$ soil at the end of the experiment. Endospore levels also initially decreased but then increased to levels equal to or greater $\left(5.4-5.6 \log _{10}\right.$ spores/g soil) than that initially applied. In all cases, the number of rifampicin-resistant bacteria recovered after 28 days was seen to be similar to the level of endospores in the inoculum applied.

Microbial survival and colonisation in the rhizosphere and rhizoplane of pea seedlings

The initial inoculum concentration on the pea seeds for $B$. subtilis LU1241R was $8.2 \log _{10} \mathrm{cfu} / \mathrm{seed}$ with $7.6 \log _{10}$ endospores/seed, and for $P$. polymyxa LU1133R, $8.3 \log _{10} \mathrm{cfu} / \mathrm{seed}$ with $8.0 \log _{10}$ endospores/seed.

No bacteria were recovered on the rifampicin-amended agar from the untreated control seedlings (data not shown). Rifampicin-resistant bacteria were recovered from the rhizoplane and rhizosphere soil of pea seedlings that had been grown from seeds treated with $B$. subtilis LU1241R and P. polymyxa LU1133R (Table 1). In general, significantly higher bacterial numbers were recovered from the top root portion compared with the bottom for both bacteria. For B. subtilis LU1241R, significantly higher bacterial counts were recovered from the rhizoplane compared with the rhizosphere for both the top and bottom root portions. With $P$. polymyxa LU1133R there was no significant difference in the number of bacteria recovered from the rhizosphere and rhizoplane for the top root portion. However, there were significantly higher bacterial populations recovered from the rhizoplane of the bottom portion compared with the rhizosphere. Recovery of endospores for both bacterial strains was relatively high (4.4-6.5 and 3.6-6.5 $\log _{10}$ cfu/g soil, respectively for LU1241R and LU1133R) compared with the total cfu counts (4.0-7.0 and 4.5-6.6 $\log _{10} \mathrm{cfu} / \mathrm{g}$ soil, respectively for LU1241R and LU1133R), and followed similar patterns of distribution between top and bottom root portions and between rhizoplane and rhizosphere. 

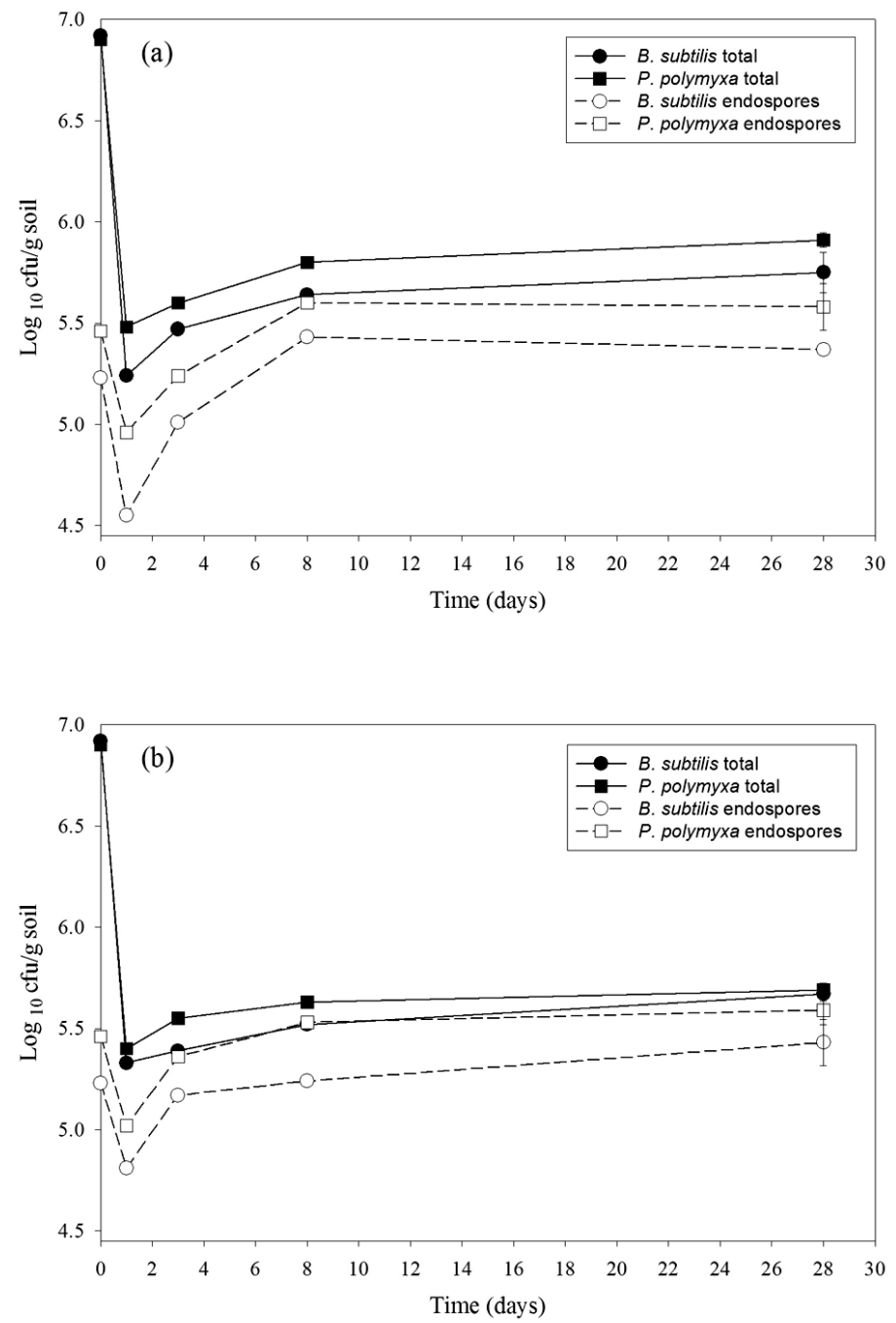

FIGURE 1: Survival ( $\log _{10}$ colony forming units (cfu)/g soil) for B. subtilis LU1241R or $P$. polymyxa LU1133R as total cells and endospores in (a) Courtenay and (b) Methven soils over time. Bars represent LSD values (except B. subtilis endospores at Courtenay, which was not significant) for comparing between all sampling times (apart from the initial counts, which were not included in the analysis), for a given treatment. 
TABLE 1: Recovery of $B$. subtilis LU1241R and $P$. polymyxa LU1133R as total cells and endospores $\left(\log _{10} \mathrm{cfu} / \mathrm{g}\right.$ soil) from the rhizosphere and rhizoplane of pea seedlings grown in non-sterile soil for 10 days.

\begin{tabular}{ccccccc}
\hline & Root & \multicolumn{2}{c}{ B. subtilis LU1241R } & & \multicolumn{2}{c}{ P. polymyxa LU1133R } \\
\cline { 3 - 4 } \cline { 6 - 7 } & Portion & Total cells & Endospores & & Total cells & Endospores \\
\hline Rhizosphere & Top $(0-4 \mathrm{~cm})$ & $6.3 \mathrm{~b}^{1}$ & $5.7 \mathrm{c}$ & & $6.6 \mathrm{a}$ & $6.2 \mathrm{a}$ \\
& Bottom $(5-8 \mathrm{~cm})$ & $4.0 \mathrm{c}$ & $4.4 \mathrm{~d}$ & & $4.5 \mathrm{c}$ & $3.6 \mathrm{c}$ \\
\multirow{3}{*}{ Rhizoplane } & Top $(0-4 \mathrm{~cm})$ & $7.0 \mathrm{a}$ & $6.5 \mathrm{a}$ & & $6.2 \mathrm{ab}$ & $6.5 \mathrm{a}$ \\
& Bottom $(5-8 \mathrm{~cm})$ & $6.1 \mathrm{~b}$ & $6.1 \mathrm{~b}$ & & $5.9 \mathrm{~b}$ & $5.8 \mathrm{~b}$ \\
\hline
\end{tabular}

${ }^{1}$ Means followed by the same letter within a column are not significantly different at $\mathrm{P}=0.05$.

\section{DISCUSSION}

Both B. subtilis LU1241R and P. polymyxa LU1133R were seen to survive for at least 28 days when applied to soil as cell suspensions containing high endospore levels. However, when applied as mostly cells, no survival of the bacteria was seen. Additionally, recovery was similar to the endospore levels applied, indicating that the cells may not survive well in non-sterile soil. Bennett et al. (2003) reported a similar trend in the survival of $B$. subtilis in non-sterile soil. Recovery of the two bacteria in the present study was higher than that found by Bennett et al. (2003), and probably reflects the higher ratio of endospores to total cells in the inoculum applied. In a study by van Elsas et al. (1986), the population of an introduced $B$. subtilis in two soils was observed to decline rapidly and to stabilise to the level of the added endospores. This suggests that applying the biocontrol bacteria as inoculum containing high endospore numbers would provide the best potential for survival of the biocontrol agents in soil. The inconsistency in biocontrol by the two bacterial strains, B. subtilis LU1241 and P. polymyxa LU1133, reported by Wakelin (2001) may, in part, be due to differences in endospore concentrations applied in different field experiments. Unfortunately, the ratio of endospore to total cells was not determined in their study.

One of the major constraints to effective biocontrol by seed treatments is colonisation of the rhizosphere and rhizoplane by the introduced biocontrol agent (Deacon 1994). Both B. subtilis LU1241R and P. polymyxa LU1133R were shown in the present study to rapidly colonise the rhizosphere and rhizoplane of pea seedlings after planting seeds coated with bacterial inoculum containing high endospore levels, potentially protecting the infection court from A. euteiches colonisation. However, as the pathogen can infect pea plants throughout the growing season (King \& Parke 1996), it will need to be determined whether this colonisation level is sustained over the growing season.

Both bacteria were recovered at a higher concentration from the top compared with the lower root sections. This can probably, in part, be attributed to the short time period (10 days) over which the experiment was run with the seedlings being relatively young at harvest. Similar results were reported by Walker et al. (2002), where for five biocontrol strains, bacterial numbers were higher on sugar-beet roots near the seed, with numbers declining on roots away from the inoculation point. It was suggested that adsorption of the bacteria onto soil, sloughing off of bacteria from growing roots or their inability to keep pace with root growth could account for this difference in colonisation. Additionally, in the present study bacterial colonisation of the rhizoplane was higher than that found in the rhizosphere and may be related to higher root exudate concentrations found in the rhizoplane.

No rifampicin-resistant bacteria were recovered in the control soils. Resistance to rifampicin in soil bacteria is unusual as it is mediated by a chromosomal mutation in the $\beta$-subunit of RNA polymerase and is considered stable and less easily transferable than a plasmid-borne marker (Compeau et al. 1988). 
This study has demonstrated the use of rifampicin-resistant strains to determine the survival and rhizosphere/rhizoplane colonisation of potential bacterial biocontrol agents in non-sterile soil. Furthermore, by recovering both endospores and total cells, information on the population dynamics and mode of survival of the bacteria has been obtained and illustrates the advantage of using formulations containing high endospore numbers.

\section{ACKNOWLEDGEMENTS}

This project was funded by the New Zealand Foundation for Research, Science and Technology - Technology for Business Growth funding, the Foundation for Arable Research, HortNZ and Agrimm Technologies Ltd.

\section{REFERENCES}

Alexander DB, Zuberer DA 1991. The use of chrome azurol S reagents to evaluate siderophore production by rhizosphere bacteria. Biology and Fertility of Soils 12: 39-45.

Bennett AJ, Leifert C, Whipps JM 2003. Survival of the biocontrol agents Coniothyrium minitans and Bacillus subtilis MBI 600 introduced into pasteurised, sterilised and non-sterile soil. Soil Biology and Biochemistry 35: 1565-1573.

Compeau G, Al-Achi BJ, Platsouka A, Levy SB 1988. Survival of rifampicin-resistant mutants of Pseudomonas fluorescens and Pseudomonas putida in soil systems. Applied and Environmental Microbiology 54: 2432-2438.

Deacon JW 1994. Rhizosphere constraints affecting biocontrol organisms applied to seeds. In: Martin T ed. Seed treatment: Progress and prospects. BCPC Monograph NO57, Thornton Heath BCPC Publications, UK. Pp. 315-326.

King EB, Parke JL 1996. Population density of the biocontrol agent Burkholderia cepacia AMMDRI on four pea cultivars. Soil Biology and Biochemistry 28: 307-312.

Opelt K, Berg G 2004. Diversity and antagonistic potential of bacteria associated with bryophytes from nutrient-poor habitats of the Baltic Sea coast. Applied and Environmental Microbiology 70: 6569-6579.

Oyarzun P, Gerlagh M, Hoogland AE 1993. Relation between cropping frequency of peas and other legumes and foot and root rot in peas. Netherland Journal of Plant Pathology 99: 35-44.

Pfender WF 1984. Aphanomyces root rot. In: Hagedorn DJ ed. Compendium of Pea Diseases. The American Phytopathological Society, St. Paul, USA. Pp. 25-28.

van Elsas JD, Dijkstra AF, Govaert JM, van Veen JA 1986. Survival of Pseudomonas fluorescens and Bacillus subtilis introduced into two soils of different texture in field microplots. FEMS Microbiology Letters 38: 151-160.

Wakelin SA 2001. Biological control of Aphanomyces euteiches root rot of pea with spore-forming bacteria. PhD thesis. Lincoln University, Canterbury, New Zealand. $174 \mathrm{p}$.

Wakelin SA, Walter M, Jaspers M, Stewart A 2002. Biological control of Aphanomyces euteiches root-rot of pea with spore-forming bacteria. Australasian Plant Pathology 31: 401-407.

Wakelin SA, McCarthy T, Stewart A, Walter M 1998. In vitro testing for biological control of Aphanomyces euteiches. Proceedings of the 51st New Zealand Plant Protection Conference: 90-95.

Walker R, Rossall S, Asher MJC 2002. Colonisation of the developing rhizosphere of sugar beet seedlings by potential biocontrol agents applied as seed treatments. Journal of Applied Microbiology 92: 228-237.

White JGH 1987. The importance of peas in New Zealand Agriculture. In: Jermyn WA, Wratt GS ed. Peas: management for quality. Agronomy Society of New Zealand special publication No. 6, Lincoln, New Zealand. Pp. 7-11. 